\title{
Making Education Markets Through Global Trade Agreements
}

(forthcoming in Globalisation, Societies and Education, 15 (3), Special Issue on 'Making Education Markets and Trade'

\author{
Susan L. Robertson \\ University of Cambridge, UK \\ slr69@cam.ac.uk
}

\begin{abstract}
This paper uses the global trade negotiations and agreements, which include education sectors as potentially tradeable services, to show the complex processes at work in making global education markets. Drawing on the work of Jens Beckert and others, I focus on the micro-processes of making capitalist orders, and the challenges at hand in bringing decommodified sectors, like education, with distinctly different narratives to sustain their purpose. These processes include reimagining and offering alternative narratives to the idea of education as a public service; the reformatting the education into the language of trade and legal documents; the use of devices, such as forecasting to represent the gains to be had into the future of trade agreements, or dispute settlement mechanisms to manage claims; and the strategic use of space and time as political resources to minimize frictions and lock in a preferred future for investors. I conclude by arguing that the ongoing circulation of alternative narratives about education makes instituting education particularly challenging, so that the future for investors is in no more way certain, despite efforts to reorient expectations.
\end{abstract}

Keywords: Trade agreements, globalization, markets, neoliberalism, fictional expectations, capitalism 


\section{Introduction}

In a widely cited report on the global value of the education sector - analysts working for the Merrill Lynch Bank of America stated it was at the time worth around \$4.5-5 trillion, and expected to grow to \$6-8 trillion by 2017 (Harnett et al., 2014: 6). In anyone's language, this is a huge figure. Yet as the contributors to this special issue are all exploring in new and interesting ways, it is important to remember there is considerable distance between asserting the dollar value of the sector both now and into the future, and the wholesale transformation of education into a profit-producing enterprise on a grand scale. This is because framing education in this way, embedding it in institutions, and normalizing education as a sector for global investors, takes a great deal of cultural, political and economic 'work'.

Much of this work entails a complex set of processes: reframing education so as to give it a new meaning, formatting education in ways that are legible to trade departments and investors; the creative use of devices - such as forecasting, investment advice and credit to make markets work; embedding new market logics into institutional arrangements and their governance architectures to reproduce markets; and, the deployment of spatial and temporal strategies to manage frictions and the inevitable contestation around the transformation of a social good into a commodity, whose taken-for-grantedness is yet to become more stable.

Global trade negotiations and agreements, for example, the World Trade Organization's General Agreement on Trade in Services, and the recent mega trade deals such as the Trans Pacific Partnership (TPP) and the Comprehensive Economic Trade Agreement (CETA), are particularly interesting entry points into studying global education markets. It is because here we can see education markets in the making through the unbundling of education as a public service, the reframing, reformatting and standardizing of education to enable its exchange in the market, 
and the deployment of various strategies and devices to institute and normalise education as a global services sector governed through global trade rules. In this paper I pay particular attention to these ongoing efforts aimed at privileging a future that is controlled by global investors. Theoretically, I draw on the work of Jens Beckett and his sociology of capitalism in that he pays particular attention to the how, or the micro-foundations, of making capitalist futures. Methodologically I draw upon a range of publicly available and leaked documents on these different agreements, as well as secondary literatures on trade deals and their ongoing negotiation.

\section{Making Capitalist Futures - A Focus on Agents and Action}

Any argument around education, and its inclusion more directly in the process of capital accumulation, suggests the need to look closely at not only capitalism as a macro-socio-economic and political dynamic, but the micro and detailed ways in which micro-level social, spatial, and temporal ordering practices are engaged to produce new cognitive orientations to the world. In short, to ask Gramsci's (1971) question: how do actors acquire a new commonsense around the role of education in society? Jens Beckert's focus on the micro-foundations of capitalist social orders is particularly helpful in answering this question. By micro-foundations Beckert means the social practices or actions of agents whose structurally-inscribed agency produces and reproduces capitalist social orders and futures (cf. Beckert, 1996, 2014, 2016).

To make more visible the distinctive of the temporal order of capitalism, Beckert (2014: 3) draws attention to French sociologist, Pierre Bourdieu, and his accounts of the Kabyle people in French-controlled Algeria. Bourdieu was particularly interested in changes in temporal order within Kabylian society as a result of capitalist modernization in Algeria. He notes how the social and temporal logics of traditional Kabylian society, of solidarity and honour, were eventually replaced by attitudes toward calculation and future profits. This led to "...conflicts in Kabylian 
society triggered by different forms of economic thinking and new practices which were ultimately destroying the traditional social order" (op. cit: 4). The main point to be derived from looking at the breakdown of a traditional society like this, Beckert argues, is to "...highlight the shift in temporal orientation as being at the heart of capitalism's unfolding dynamic" (ibid).

And it is 'the future' and the role it plays in capitalist dynamics which is particularly pertinent to this analysis of making markets through trade agreements. 'The future' in capitalism is not one sided. Modern capitalist societies see the future as open and uncertain as well as a store-house of possibilities for future innovation and investment. This in turn means investing in efforts to manage the future, as well as how to exploit the future. As a result; "...the capitalist economy specifies systemic pressures that enforce a temporal orientation toward future economic opportunities and risks. Only by examining these institutionalized pressures may we comprehensively shed light on the role of actors temporal orientations with regard to economic processes" (Beckert, 2016: 3-4).

Two institutional mechanisms are identified by Beckert as key to enforcing the future orientation of actors in capitalism: that of competition, and credit (Beckert, 2016: 4). Competition forces actors to remain alert to threats, and to seek new opportunities to overcome threats. Credit enables entrepreneurs and firms to engage in economic activity that could not otherwise be undertaken, using resources they have yet to earn. An example here is the role of venture capitalists global financial institutions like the International Finance Corporation who have provided credit to new education providers like Bridge International Academies (see Riep in this issue) to open new education markets in Africa.

Yet despite the future being unknown, actors have perceptions of the social world and develop expectations about the future that in turn influences their decisions. But because these decisions cannot be 'rational' (in the ways in which rational choice theorists think about future as predictable) in that, given the future is unknown, they are in essence 'fictional expectations'. All they can do is provide an orientation in decision-making "...despite the incalculability of the outcomes" 
(Beckert, 2014: 9). They are also 'expectations' in that they are social and not individual phenomena, and are shaped by collective beliefs formed from communicative practices ranging from laypeople to firms, politicians, experts and the media, and are crucial in the formation of imagined futures. "Actors, motivated by an imaginary future state, organize their activities based on this mental representation and the emotions associated with it" (Beckert, 2016: 9). As a result, "in economic practice, fictional expectations take a narrative form, and become articulated as stories that tell how the future will look and how the economy will unfold into the future from the current state of affairs" (Beckert, 2016: 10). These stories are embedded in frames, which include an ensemble of economic theories, such as development, risk and calculation, or technological progress, and are mediated through the deployment of a range of strategies and devices, such as formatting tools, statistical trends, impact assessments, detailed and complicated clauses and annexes in trade agreements, and a range of means of mediating or managing out potential other stories or narratives about the way the world could work (see Robertson, 2017).

In the following sections I illustrate how such a politics of expectations underpins the discursive, material and institutional work involved in challenging current imaginings, reimagining education as a market, and embedding new institutional arrangements like trade agreements so as to socialise and normalise global trade in education in the face of struggles over the meanings and purposes of education and its governance. Actors' different expectations and their associated imaginaries around education - as variously a public good, human right or tradeable service have become the flashpoints around which political struggles over education into the future. This has led to trade negotiators, under pressure from their respective governments and investors, to strategically use space and time to limit alternative narratives of the future and education from being realised. 


\section{Challenging Existing Framings of Education: the Burden of Public Regulation}

In April 1999, the Institute for Economic Affairs, together with the International Finance Corporation (IFC), published the results of a commissioned report on the role of private providers in education. From the vantage point of 2017 and looking back, this report entitled The Global Education Industry highlights the regulatory issues (viewed as impediments to trade) that at the time faced, and which continue to face, corporations wanting to operate in the education sector.

The Report is notable for other reasons. First, the International Finance Corporation, part of the World Bank Group, is visible almost for the first time as a global actor in the education sector, and one who has over time taken on a bigger and bigger role aimed at opening up education markets in low-income countries. In the Foreword to the Report, the IFC's Vice President for Finance and Planning, Birgitta Kantola, points out that the IFC, the private sector lending arm of the World Bank Group, intended to move into new investment areas as a result of becoming “...increasingly aware of the potential to participate in private education" (Tooley, 1999: 7). By 2001, the IFC began framing education as an 'emerging market'. In doing so, it effectively equated education with other trade domains, such as tourism, extractive and other primary industries.

Second, the report was written by Professor James Tooley, well known throughout the 1990s for his writings on the relationship between the state and education. His books, Disestablishing the School (1995), and Education Without the State (1996), had already marked him out as a controversial figure both in the UK and globally, especially his opposition to the state education. In these two books, Tooley argued state governed education was failing to properly educate, and that state government regulations increased inequalities. The solution, he argued was to open opportunities for educational entrepreneurs to create a market-based rather than state-based or public education sector.

Tooley's Global Education Industry (1999) report highlighted the extent of corporate activity in low-income countries, and the conditions that he argued might 
enable it to expand. Education corporations were argued to be the 'least risky ventures' (p. 23) because the corporations had to worry about the value of their brand. Tooley also argued this kind of education establishment would also help grow the next generation of entrepreneurs amongst the populations it operated in, and provide education to families not well served by the public education system.

Particular attention is drawn by Tooley to the frustrations faced by investors wanting to enter into the education sector - through the capitalist investor is framed here in Tooley's text as an education entrepreneur. The biggest challenge to the expansion of private education and the creation of a global education industry, he noted, was the regulatory environment (Tooley, 1999: 95-104). A selection of quotes from the Report illustrates these arguments:

...although regulations may be intended to protect consumers and maintain standards, they often act to inhibit, and in some cases stifle, needed educational opportunities which the private sector could otherwise provide.

There appear to be three ways in which regulatory regimes can inhibit private growth and investment: (i) regulations are substantial, but mainly ignored; however the threat of enforcing them inhibits and threatens operations; (ii) regulations are applied in an arbitrary or ad hoc fashion, and (iii) petty regulations are enforced, leading to inconvenience, inefficiency and a brake on growth (p. 95).

Tooley draws attention to regulations that that enforced in education systems in a country like Zimbabwe: a mandatory curriculum, he suggests argues, inhibits the ability of private schools to compete with each other around curriculum content; provisional registration and the threat of withdrawal of recognition status of the provider makes it difficult to attract students to start up an operation (p.98); the insistence on compliance with The Teacher's Statute which regulates the labour contract for teachers means private providers cannot run their own system of incentives (p.99); and strict planning rules and regulations around marketing and recruiting international teachers limits the development and expansion of a school market (p. 100). 
Tooley uses case studies on Brazil, India and Turkey to show similar kinds of challenges facing capitalists investing in education as private for-profit operators. In his conclusions Tooley argues private sector companies have much to offer the development agenda more generally, and innovation and equity in the education sector, specifically. Unless regulations were liberalised in education, he argues, education corporations are unlikely to emerge and prosper (p.122). Here international organisations, such as the IFC, are turned to as having an important role to play, not only in helping change the climate of receptiveness to corporations interested in investing in education, but by lending investment funds, or credit, to companies wanting to expand into the sector (ibid: 126), two of the key institutional mechanisms pointed to by Beckert (2016: 4) to enforce the future orientation of actors in capitalism.

Nearly two decades on, and ongoing efforts to reframe education as a competitive market have expanded to the point that the idea of a global education industry has been normalized. However efforts to reformat and institute the governance of education services in global trade architectures in ways that privilege capitalist investors and competitive governments has been limited, though the recent round of agreements (TPP and CETA) show that if these were to be finally signed off, they will be subsumed within the rules governing global economic markets. What is important, however, in reviewing these ongoing strategic efforts, is to show the ways in which the reframing of education as a competitive market has in turn been used as a basis for why it cannot be exempted from inclusion in global trade deals, and how strategically managing space through processes like rescaling and secrecy, has been used to advance the creation of capitalist market-making in education. In the section which follows I detail the considerably reframing that has taken place via competition before turning to the ways in which formatting (building on formatting of education as a service from the GATS agreement) and a range of devices which have been put to work to help roll out the latest set of agreements (TPP, CETA) that have been concluded. 


\section{Reimagining and Reframing Education Via Competition}

A first shift in reframing centred on transforming the mandate for education and how the sector might be governed using principles of competition from capitalist markets. A key mechanism was the use of neoliberal ideology to reimagine and guide a new development model for governments around the world. This entailed the rolling back of the post-war welfare state (Tickell and Peck, 2003) and the rolling out of a new political project that would transform the economic and social landscapes of many countries around the world. The economic crisis in the early 1970s provided the entry point for early work in orchestrating this shift. Neoliberals argued the future wealth of nations depended on cutting the cost of government and creating the conditions whereby the private sector could boost productivity through competition, efficiencies, and innovation-driven profits. Beginning with Chile in the 1970s (Peck, 2010), then later the United States of America (USA), the United Kingdom (UK), Australia, and New Zealand, amongst others, exponents of free markets and neoliberalism promoted the liberalisation of existing economic arrangements (tariffs, financial regulations), the privatization of key public sector activities (state-owned enterprises like utilities), and the marketization of public services, like health and education (Harvey, 2005). Leys (2003) describes this as market-driven politics aimed at creating a market society. A visible manifestation of this shift in the schooling sector was the introduction of choice policies that drove competition, along with opening out the sector to new providers. Similar features appear in the higher education sector, though competition for students extended out into the international arena.

A second shift in reframing education was the reconceptualization of its purpose; as a key sector to promote the stock of human capital and knowledge, on the one hand, and to boost creativity and innovation to feed the development competitive knowledge-based economies, on the other. A raft of initiatives were launched: these ranged from widening access to education against targets; greater levels of investment in research and development in universities; the launch of programmes to produce entrepreneurs; the creation of incubators in universities to generate 
patents and spin-out firms; and the development of infrastructures, like technology transfer offices to boost the connection between knowledge creation and value creation.

A third shift has centred on the possibilities for rapidly generating new knowledge from large amounts of data, as well as to transport knowledge in immaterial forms. In essence, this third dynamic involves the constant reframing of knowledge into digitally-driven information which has changed the scale of the production of information and knowledge and modes of access. In the education world, knowledge products that can be digitized, such as e-books, are now no longer constrained by the limitations of physical storage. Libraries are able to hold more stock because some of it is virtual, though this does not mean that they have widened access. Digital locks and other devices manage the value chain. Digitally collected information, or big data, is now an important building block for new products and services around the creation, storage, analysis, sharing and innovative recombining of data and information. For instance large student satisfaction surveys with their university experience carried out by companies, like i-Graduate or the Princeton Review, gather data and sell information to students as to where best to study. Massive Open Online Courses (MOOCs), which emerged around 2010, now sit on platforms which generate learning analytics data. Companies like LinkedIn not only connect data on the learning and employment profiles of individuals, but they also use this information to create new services around recruitment (Komljenovic, 2016). The Cloud is also routinely used to store education-related data from libraries of papers to large data-sets. Facebook is used by education institutions to bring groups of learners and other study groups together, as well as being a means of keeping in touch with alumni. However, these global companies do not reach into each country; China for instance places limits on the operation of digital firms inside its borders - such as Facebook and YouTube. Information can now command a premium in terms of value, whilst the infrastructures of the Internet, such as platforms, are able to charge significant rents over time. 
It follows that with such a significant investment in, and dependence upon, the 'global education services market' - that investors, governments, and institutions, have given some thought as to how to maintain or increase their share of the various education services markets - from recruiting international student mobility (see Komljenovic, 2017 in this issue), to attracting talented high skilled labour, the recognition of credentials, the sale of learning products, fee-for service quality assurance, the list goes on. It should come as no surprise that these actors have also been active in trade talks, and particularly following the 2008 global financial crisis, as pressure has grown to open up education sectors to a wider range of actors, selling a wider array of services across territorial boundaries.

\section{Formatting Education as A Tradeable Service}

It is one thing to reimagine, and reframe, education as a competitive sector producing knowledge and skills for the economy and wider society. It is quite another thing to 'reformat' education in such a way that it can be talked about in terms similar to trading in goods - much as in the General Agreement on Tariffs and Trade (GATTS), which organised global trade in the post-World War II period (Kelsey, 2008). For example, when governments report on GDP, they report on the dollar value of goods and services that have been produced in any one year as a measure of economic activity. When governments report on export from various goods and services, they are reporting on the dollar value of what has been earned by that country. More recently, governments have been representing education as a sector in their export figures, but what is the basis of this measure.

Until recently, education had not been formatted in such a way that it can be measured and represented in trade figures. Rather, education tended to be talked about in terms of inputs (e.g. \% of GDP spent on education) and outputs (e.g. number of 15 year olds with a leaving school qualification; \% of GDP spent on R\&D). But spending money on a sector, or measuring the outputs by way of credentials is 
very different to measuring the value of the sector in trade terms. This is because, as a public service, it was not a commodity in market exchanges. As a service, it is intrinsically social, and even if privately provided - such as by the church or a charity, its social relations are likely to be socially ascribed (such as in the production of elites) rather than economically described. As Kelsey observes of public services more generally; "Their form and content has been designed to deliver a range of functions: individual well-being, employment, training, infrastructure, communications, community development, regional development, economic development, and cultural transfer" (Kelsey, 2003: 268).

The first major effort at formatting education in such a way that it can be included in, and regulated by, global trade rules, was to translate education as a public service into a legal form as a services sector using the GATT. This occurred with the General Agreement on Trade in Services (GATS) - launched in 1995 with the establishment of the World Trade Organization. The WTO's mandate was to “...formalize, deepen and widen an international system of trade regulation (Wilkinson, 2002: 129). Yet there were problems in defining services like education using the language of trade in goods. As Winham points out:

...services are processes, defining them is difficult, unless a strict functional definition is employed. ...The tasks for the negotiators at the Uruguay Round were to incorporate GATT principles of transparency, national treatment and reciprocity, as well as newer principles such as market access, into areas of trade that were conceptually dissimilar from trade in goods (2005: 101).

The result was a service agreement that was; “...not yet complete, not terribly user friendly, with a complex geometry and al a carte obligations set against the backdrop of near universal coverage and sovereign immunity in liberalization matters" (Sauve, 2002: 3). However as Kelsey observes, in drawing on the GATT in this way (rule-based trade) it also implied an equivalence between services and industrially-produced goods and in doing do, foreclosed any debate around the social nature of services (Kelsey, 2003: 270). 
The complexity of this rules-based format in turn is strategically selective of legal expertise and trade negotiators. For instance, members who joined the WTO are described as opting in under 'a single undertaking' to a series of 'legally-binding rules' and a 'built-in agenda' to engage in 'on-going negotiations' leading to 'progressive liberalisation'. All sectors of education were included in GATS, though it was then up to the negotiators as to which modes and sectors might be listed for agreement.

The GATS format has three components. The first is a framework of rules that lay down the general obligations governing trade in services, much as it did with the GATT. It also laid out basic elements, such as; 'transparency' of all regulation at all levels of government and including also non-governmental bodies exercising governmental power or authority (regarded as very important given the density of services trade), 'most-favoured nation' (MFN) treatment, 'market access' and 'national treatment'. In the second component there are annexes on specific service sectors, like education, as well as the movement of natural persons. The third component consists of 'schedules of commitments' detailing the liberalisation commitments of each WTO member.

The GATS also distinguishes between 'four modes of supply' through which services can be traded: Mode 1: cross border supply; Mode 2: consumption abroad; Mode 3: commercial presence; and Mode 4: movement of natural persons. According to this GATS framework, an exemption can only to granted to a services sector to remain in the public domain if, as specified under GATS Article 1.3 it is supplied "...in the exercise of governmental authority" (Art 1.3(b)), and is "supplied neither on a commercial basis nor in competition with one or more service providers" (Art. 1.3 (c)). Governmental authority here was interpreted in a narrow sense (WTO, 1998; see also Krajewski 2016: 2-3). That is, the idea of governmental authority is only applicable to core sovereign functions and not applicable where there is any remuneration, or where there is evidence of competition - meaning there are one or more service suppliers. In essence, education is difficult to exclude a priori in 
many WTO countries in that they have introduced elements of competition into the governance of their education sectors, as described above.

Aside from the technical details, it is important to note the formatting of education into a legal, contractual, language with mechanisms such as Dispute Settlement to resolve differences between countries and investors. As Kelsey argues, overnight the reformatting of education into the language of the GATS meant that education was "...magically transformed into an expression of objective reality and an abstract normative instrument based on general principles, rules and technical terms. Those who accepted its legitimacy represented the assumptions as, values and interests that underpin the Agreement as unquestionable and timeless" (Kelsey, 2003: 269)

Formatting education in this way also transforms the meaning of education in that as a service it is not only abstracted, but it is also fragmented. The core activity of a university falls under post-Secondary technical and vocational services. Other higher education services, Adult education services, Sporting services, Research and experimental development services on natural sciences and engineering, and so on, all fall under different codings (Kelsey, 2003: 275). This is taken one step further with Public Private Partnerships in that the services are disaggregated in accordance with the operational principles of the contracted firm - in the form of procurement, financial services, labour and the like.

The GATS formatting of education, as a services sector governed by international trade rules, has been extended out into other trade agreements, such as the bilateral agreements between countries (e.g. Singapore and the US; Europe and South Korea), as well as into the current round of recently completed or still under way trade agreements. These include the Trans-Pacific Partnership (TPP) involving 12 countries in the Pacific Region dominated by the United States; the Comprehensive Economic Trade Agreement (CETA) between Canada and Europe; the Transatlantic Trade and Investment Partnership (TTIP) involving Europe and the United States; and the Trade in Services Agreement (TISA) largely between OECD countries. 
A related but different kind of formatting concerns efforts to measure and generate a value for the education sector, and its worth as an export. Different countries calculate these differently, even through they may well be compared with each other for competitive purposes. The first step is to define what counts as an education export, which may or may not equate to the GATS conception of education exports. In a policy document launched in 2013 to promote the expansion of education exports as a strategic sector, the UK government (BIS, 2013: 21) stated: "Education exports are defined as those activities where money comes to the UK from an overseas source, either for an education-related activity taking place in the UK (e.g. international students studying at a UK HEI) or from an education-related activity occurring overseas (e.g. TNE)". The Australian Government, on the other hand, using the Australian Bureau of Statistics categories, refers to the fees and goods and services paid for by international 'onshore students' as 'education-related personal travel' (Department for Education and Training, 2014).

The next step is to decide what to itemise as generating value; for the UK calculators in 2013, this included tuition fees, living costs, language costs, and 'other'. These figures are then broken down by sector and (higher education, schools, language schools, further education) and education products and services. The final value of education exports was then estimated to be $£ 17,490$ billion. Aside from economic value, other values are claimed, such as the reputational value of UK education and promoting British values. Unlike the UK, the Australian government includes distant learning (referred to as 'correspondence courses) and consultancies in their figures.

The central task here for governments and industry is valuation and pricing so as to enable a market to function. And indeed, argues Aspers and Beckert (2011: 30) markets fail if the problem of valuation cannot be resolved. There has been very little work, however, on this aspect of education markets; the socially-constructed nature of the value of an education service, and the processes of formatting and evaluation that are deployed to arrive at decisions. These might include the 
difference between standard markets and status markets (e.g. bog standard versus ivy league universities), the role of judgement (e.g. what is being used to decide), and the concept of singularity versus heterarchy (e.g. an education credential only versus an education credential plus social networks and access to political power) (Aspers and Beckert, 2011: 31).

\section{Devices}

I have made the point above that markets do not come into existence without considerable work at generating equivalences between social activity and economic activity, and from there, economic activity into competitive market activity that is dynamic and innovative. Formatting thus describes the 'what', or the meaning of something. However a series of devices or instruments, or the matter of 'how', can be shown to be fundamental to the work of global market making.

The Agreements themselves are not just formatting tools but they also devices in that they are not just negotiated, but consulted, and in some cases contested through dispute processes. The Agreements are lengthy, with the TPP spanning some 5000 pages, made up of Chapters, their Rules, and Annexes specifying the detail of listings of exclusions. The Agreements are consulted by trade experts and arbitrators with regard to the detail of a claim, or of a case. They also house other devices that are put to work, and which work on, making a global education market that is regulated through trade rules.

These devices within the larger agreement include lists of exclusions and inclusions - referred to either a Positive List or Negative List. Under the GATS, a Positive List is used and it is this list - that is - what is listed, that is included in offers to negotiate. Under the TPP, CETA and the TTIP, a negative list is used. A negative list means identifying all those activities that are to be excluded so that what is not on the list is included. TISA uses a combination of a positive and negative list. It is the negative list that is the most powerful in colonizing the future for the investor, in 
that all future activity is viewed as wound into progressive liberalization automatically.

Standstill and ratchet clauses are devices within the Agreement which regulate the ongoing expansion of the global education market. By 'standstill' the recent megatrade agreements mean there can be no reversals away from the current levels of liberalization in the sector. The ratchet clause means any new activity in the sector into the future will be subject to the principles of the market and the interests of the investors, as enshrined in the trade agreement. The ratchet process thus aims to draw more and more of the society into functioning like a capitalist market. With its face to the future, and more and more competition in the sector as a result of more and more markets being opened up, the overall dynamics of the sector also has consequences for those actors in the sector whose cognitive frames will be oriented to capitalist market-making.

Investor State Dispute Mechanisms (ISDS) are devices deployed to mediate disputes between investors and governments. Over time, they have become particularly popular, with a steady rise in cases; some 70 cases were filed in 2015 (UNCTAD, 2016). As a device, they tend to work in the interests of the investors, in large part as these are ad-hoc tribunals, in part because they display a pro-investor bias, and because there is a lack of transparency around the arbitration process. Research by Van Harten (2012: 6) confirms this; drawing upon empirical evidence, he shows there is systematic bias in the arbitration resolutions in favour of the major Western capital-exporting states. The secretive nature of the arbitration process, and the lack of any requirement to consider precedent, allows plenty of scope for creative adjudications (Economist, 2014). The Economist goes on to argue that the sharp rise in contentious arbitrations are the result of companies having learnt how to exploit ISDS clauses, going as far as buying firms in jurisdictions where they apply simply to gain access to them. 
A rather different kind of device has been used to legitimize trade agreements are Impact Assessments. 'Impact Assessments' used to convince sceptics and to enrol promoters, and thus align expectations, as to the longer-term outcomes of these deals. The Impact Assessment for the TTIP was conducted by the Centre for European Policy Studies (CEPS), a pro-business think-tank located in Brussels (see Pelkmans et al., 2014). The results of the Impact Assessment were then used by the European Commission to project the annual gains to be had from the TTIP; of $€ 119 \mathrm{~b}$ for the EU, and €95b for the USA, suggesting that European countries would be the main beneficiaries.

However devices are never neutral, and nor are Impact Assessments of this kind in that it makes specific assumptions about capitalist markets and futures. De Ville and Siles-Brùgge (2015) show that the TTIP Impact Assessment depends on the Computational General Equilibrium Modelling (CGEM). CGEM embraces neoclassical economic assumptions: there is no excess demand, all markets clear under conditions of perfect competition, and we can model market processes through numerical data and results. Yet De Ville and Siles-Brùgge (2015) argue that CGE models have been subject to critique, even within economics, in that there are information asymmetries, individuals are often driven by more complex sets of values, and labour and product markets rarely clear at the same time. The CGEM was used to model three kinds of policy options for TTIP; from a baseline option to a comprehensive and ambitious one, of removing all duties, reducing tariff and nontariff barriers (NTBs) on goods and services, and on government procurement. For the base-line option, the gains are negligible. The gains on the more comprehensive scenario, the one used by the Commission to make the economic case for TTIP, were presented as more substantial. And it is this latter - more generous - imagined future that is used by the Commission in its public defense of TTIP.

De Ville and Siles-Brùgge (2015) argue that this device - an Impact Assessment acts like a black box; it not only skews the terms of the economic and political debate in directions that suit the Commission's agenda, but also has a particular narrative that it offers of the present and the future. This future does not include 
the costs that result from macro-economic adjustments - such as alignment to new standards, the displacement and retraining of workers, potential welfare losses in the society, or the threat to public policy goals (De Ville and Siles-Brùgge, 2015: 669). In contesting this Impact Assessment narrative, De Ville and Siles-Brùgge (2015) present the case of the North American Free Trade Agreement, which also used the CGEM. They compare the ex-post evidence with the ex-ante claims which show that both Mexico and Canada fared significantly worse than predicted in terms of economic gains (especially around costs over labour displacements). In relation to TTIP, they argue a combination of the assumptions built into the CGEM, the regulatory mechanism to be used, and the capacity to liberalise across the board, exaggerates the potential economic benefits of TTIP whilst under-playing other likely outcomes - such as a race-to-the-bottom in social, educational and environmental standards. Yet devices take some expertise, and effort, to open up and unpack the assumptions; all necessary to enable us to see the work that they are asked to do in both legitimizing trade negotiations and ensuring their final conclusion.

\section{Strategies and Counter-Strategies - Space and Time}

Despite the deployment of seemingly technical activity, like formatting and the deployment of devices to bring global education markets into being, the ongoing navigation of these projects requires major strategic efforts. The failure of the GATS negotiations to secure commitments, not just on education but more broadly, points to the visible politics at play when competing narratives are still circulating as to the meaning of a social activity. This was powerfully shown in the case of education and the GATS Ministerial Meeting in Hong Kong in 2005; this meeting was accompanied by protests on the street, and other organized opposition in global civil society. This was despite efforts to meet in locations with might not attract attention, or high levels of security as to who might have press or observer status. Investors and governments have also used rescaling g as a spatial strategy. 
Following the challenges facing the GATS negotiations, the free trade advocates and corporations shifted their efforts to new forums, including bilateral agreements, regional agreements and national institutions to keep advancing this agenda. This spatial strategy materializes 'forum shifting'. At the national level, interested education services providers approached nationally located regulatory bodies to make claims to enter the sector (Robertson and Komljenovic, 2017). At the regional level, agreements like European Union's Directive on Services were advanced and finally agreed to in 2006 (European Parliament and Council, 2006) (ibid). At the bilateral level, a significant number of Bilateral and Preferential Trading Agreements were advanced (Horn et al, 2010). In combination, these spatial strategies, to target different forums, moved the trade agenda forward.

Similarly investors have used a strategic engagement with place for their own purposes. Investors have used particular jurisdictions and forums to make a claim so as to get the most 'return' regarding potential investor pay-outs. The ISDS space of arbitration is also only available to foreign investors, thus privileging powerful transnational investors (large corporations) over and above nationally-located education investors. Indeed, ISDS gives exclusive rights to foreign investors; rights not available to domestic investors or citizens. Foreign investors are not even obliged to exhaust the domestic legal system before turning to ISDS. This uneven terrain is the result of different degrees of economic and political liberalisation operating vertically and horizontally, of overlapping and competing spaces and places regarding trade rules, and the capacity for the transnational corporations to skew the rules of the game toward themselves.

Each of the current trade negotiations has also sought to use space strategically, albeit it in democratically questionable ways. The TPP, TISA and CETA have all been conducted in secret; getting access to the documents has largely been the result of wikileaks. TISA is also being negotiated outside of the WTO space, though in Geneva. Secrecy has its costs as the lack of shared expectation about the future of education as a services sector places limits on its potential to get traction on, and control, share cognitive orientations to the future. 
Time is also a key political resource, and quite central to appreciating the complexities involved in market making. The challenges involved making education into a market is that its temporal orientations and rhythms are quite different to a dynamic capitalist market. To begin, the temporality of education worlds involves time orders which stretch out, rather than pace up, social life (sitting, waiting, turn taking, and so on). If the future is invoked, it is more likely to be with a concern for social mobility, or becoming someone. However capitalist markets demand constant attention to the future so as to profit from new opportunities and guard against hazards. Time-future is also political resource to be captured, whilst individual actors' orientations to this different market future need to be recalibrated so as to stabilize new meanings, practices and commonsense. Trade agreements are rich with various devices which work on this cognitive reorientation to the future. Stand-still, ratchet and progressive liberalization clauses are all aimed at this recalibration (Robertson, 2017). However in the current trade deals (TISA, TPP, CETA and TIPP) the future has also been colonized by the investors via mechanism and devices which discourage governments from putting the brakes on, or reversing decisions around the making of global markets. Such penalties, worked out in the Investor State Dispute Settlement cases, include paying the investor future lost earnings that might have been anticipated as a return. In effect, this places the economy, or the market, beyond politics. Powered on by progressive liberalization and the ratchet effect, unhindered by government regulations, gives unfettered momentum to an ever-expanding world of global market making. Future time is thus a prize worth fighting for by investors, for in doing so, they aim to claim, and contain, an as yet unknown future.

Yet time past, or memory, also tells a story about the frictions in making education markets globally; that of failed meetings, disillusioned developing countries, and the questioning of the viability of a system of global governance. These different temporally-located narratives point to the complexities of market marking and the considerable contestation and contradictions which have accompanied this process. 
Those opposing the inclusion of education in GATS during the 2000's, as well as those opposing the current round of trade negotiations and agreements which include education as a services sector, enroll a competing narrative; education as a human right and entitlement as recognized in international instruments (most prominently the International Declaration of Human Rights launched in 1948 after

World War II, and the Convention of the Human Rights of the Child launched in 1959) and a public service. In a specially commissioned report on GATS, the Special Rapporteur for Education pointed out that the "...rapid development of international trade law necessitated a decisive reaffirmation of education as a human right" (Tomasevski, 2001: 5). This led her to observe:

...the liberalization of trade in services, without adequate government regulation and proper assessment of its affects, can have undesirable effects. Different service sectors require different policies and time frames for liberalization and some areas are better left under governmental authority (p. 20)...While the WTO Agreements provide a legal framework for the economic aspects of the liberalisation of trade, they focus on commercial objectives. The norms and standards of human rights provide the means of providing a legal framework for the social dimensions of human rights...A human rights approach to trade liberalisation emphasizes the role of the State, not only as negotiator of trade rules and setter of trade policy, but also as duty bearer for human rights (Tomasevski, 2001: 10).

\section{Conclusions}

I began this paper by arguing that making education markets entails a great deal of work, and sought to show the complexities of the work through ideas like reframing, formatting, devices and the strategic use of time and space. Of course markets also need to be instituted in ways that also help in their ongoing reproduction, and it is here that there is still some distance to go with regard to global trade agreements. The GATS Agreement languishes, though the United Kingdom's intended exit from Europe, he now infamous Brexit, might provide an unexpected boost to the WTO's GATS in that it will be pressured to seek out this 
kind of forum to negotiate access to education services globally. Similarly, the CETA agreement has been concluded, like the TPP. However, the US has withdrawn support for TPP with the election of Donald Trump, whilst all of the current agreements that have been ratified in 2016/2017. are yet to be ratified by the various Member State's governments. There is a great deal at stake for investors, and a great deal to lose regarding making global education markets for those with an interest in making a profit.

With a visible return to hardening national boundaries, and next steps in the effort to secure global education markets might well be tricky work. But with economic development tied to the creation of services sectors for the West, it is difficult to see any winding back from efforts to cognitively reorient actors to making global education markets. Where the challenges and difficulties will lie is in bringing them inside global trade rules. For the moment it is clear that the creation of a global education services sector regulated through global trade agreements is a project that is still to be realized. Or, put another way, this new order and its commonsense is yet to be properly born, and an older order is yet to finally die. There is nothing inevitable the creation of global education markets. After all, as Beckert (2016) points out, the future itself is a fiction, and so must the idea of a future of global higher education markets.

\section{References}

Beckert, J. (1996) What is sociological about economic sociology? Uncertainty and the embeddedness of the economic action, Theory and Society, 25, pp. 803-40.

Beckert, J. (2014) Capitalist Dynamics, Fictional Expectations and the Openness of the Future, MPIfG Discussion Paper, 14/7.

Beckert, J., (2016) Imagined Futures: Fictional Expectations and Capitalist Dynamics, Cambridge: Harvard University Press.

BIS (2013) International Education: Global Growth and Prosperity, London: Department for Business, Innovation and Skill

Aspers, P., and Beckert, J., (2011) Value in markets, in J. Beckert and P., Aspers, (eds) The Worth of Things: Valuation and Pricing in the Economy, Oxford: Oxford University Press. 
Department for Education and Training (2014) Export Income to Australian from International Education Activity in 2013-14, Research Snapshot, November, Canberra: Department for Education and Training

De Ville, F., and Silles-Brügge, G., (2015) The Transatlantic Trade and Investment Partnership and the role of Computational General Equilibrium Modelling: An exercise in managing fictional expectations, New Political Economy, 20 (5), pp. 653678.

European Parliament and Council (2006) Directive 2006/123/EC of the European Parliament and of the Council of the 12 December, 2006 on services in the internal market, Official Journal of the European Union, 27th December, Brussels: European Unions.

Gramsci, A., (1971) Selections From Prison Notebooks from Antonio Gramsci [edited and translated by Q Hoare and G. Nowell Smith], New York: International Publishers.

Hartnett, M., Leung, B., and Marcus, J., (2014) A transforming world, The Thundering World, New York: Bank of America, Merrill Lynch available at https://mlaem.fs.ml.com/content/dam/ML/Articles/pdf/ATW-The-ThunderingWord.pdf - last accessed 5th May, 2017]

Harvey, D. (2005). A Brief History of Neoliberalism, Oxford University Press: Oxford.

Horn, H., Mavroidis, P., and Sapir, A., (2010) Beyond the WTO? An anatomy of EU and US preferential trade agreements, The World Economy, 33 (11), pp. 1565-88

Kelsey, J., (2003) Legal Fetishism and the Contradictions of the GATS, Globalisation, Societies and Education, 1 (3), pp. 267-80.

Kelsey, J., (2008) Serving Whose Interests? The Political Economy of Trade in Services Agreements, London and New York: Routledge-Cavendish.

Komljenovic, J., (2016) Making Higher Education Markets, unpublished PhD thesis, University of Bristol.

Komljenovic, J., (2017) Market Ordering as a Device for Market-making: The Case of the Emerging Students Recruitment Industry, in Globalisation, Societies and Education, 15 (3) pp.

Krajewski, M., (2010) Model clauses for the exclusion of public services from trade agreements, European Public Service Unions with Gerechtigkeit Muss Sein.

Leys, C., (2003) Market-Driven Politics: Neoliberal Democracy and the Public Interest, London and New York: Verso

Peck, J., (2010) Constructions of Neoliberal Reason, Oxford: Oxford University Press.

Pelkmans, J., Lejour, A., Schrefler, L., Mustilli, F., and Timini, J., (2014) The Impact of TTIP: The underlying economic model and comparisons, Brussels: Centre for European Policy Studies, No. 92, October. 
Robertson, S., (2017) Colonising the Future: Mega-Trade Deals, Education Services and Global Higher Education Markets, Futures, available at http://dx.doi.org/10.1016/j.futures.2017.03.008

Robertson, S., and Komljenovic, J. (2017). Forum shifting and shape making in Europe's negotiations on trade in(Higher Education) Services. In R. Barnett, M. Peters and R. Heraud (eds.), The Global University, Frankfurt: Peter Lang.

Tickell, A., and Peck, J., (2003) Making global rules: globalisation or neoliberalism? In J. Peck and H. Yeung (ed.). Remaking the Global Economy, London: Sage.

The Economist (2014) The arbitration game, 11 $1^{\text {th }}$ October [accessed at http://www.economist.com/news/finance-and-economics/21623756governments-are-souring-treaties-protect-foreign-investors-arbitration - on 5th May, 2017].

Tomasevski, K., (2001) Annual Report of the Special Rapporteur on the Right to Education, submitted to the Commission on Human Rights, Economic and Social Council, New York.

Tooley, J., (1999) The Global Education Industry: Lessons from Private Education in Developing Countries, London: IEA and IFC.

UNCTAD (2016) Trade and Development Report, 2014, Overview: Geneva: UNCTAD.

Van Harten, G., (2012) Arbitrator Behaviour in Assymetrical Adjudication: An Empirical Study of Investment treaty Arbitration, Osgoode Hall Law School, Research Paper 41/2012, New York: New York University. Wilkinson, R. (2002) Global Monitor: The World Trade Organisation, New Political Economy, 7 (1): 129-141.

Winham, G., (2005) The evolution of the global trading regime, in J. Ravenhill (ed.). Global Political Economy, Oxford: Oxford University Press. 